\title{
Volatile Anesthetics in Ischemic Liver Injury: Enemy or Friend?
}

\author{
Masood Mohseni ${ }^{1}$; Saeid Safari ${ }^{1,2}$; Seyed Moayed Alavian ${ }^{2,3,{ }^{*}}$ \\ ${ }^{1}$ Department of Anesthesiology, Iran University of Medical Sciences, Tehran, IR Iran \\ 2 Department of Anesthesiology, Iran University of Medical sci \\ 3 Baqiyatallah Research Center for Gastroenterology and Liver Diseases, Baqiyatallah University of Medical Sciences, Tehran, IR Iran \\ ${ }^{*}$ Corresponding Author: Seyed Moayed Alavian, Baqiyatallah Research Center for Gastroenterology and Liver Diseases, Baqiyatallah University of Medical Sciences, Tehran, IR Iran. Tel: \\ +98-2188945186, Fax:+98-2188945188, E-mail:alavian@thc.ir \\ Received: April 30, 2014; Accepted: May 1, 2014
}

Keywords: Anesthetics, Inhalation; Liver Diseases; Perioperative Care; Anesthesiology; Intraoperative Care

Ischemic liver injury occurs in a variety of clinical settings such as trauma, shock, and liver surgery $(1,2)$. Ischemia and subsequent reperfusion injury rapidly evolves to sinusoid endothelial cell damage, activation of Kupffer cells, inflammation, hepatocyte necrosis and finally liver dysfunction, especially in patients with preoperative liver injures (3). Liver failure is associated with a risk of poor outcome (4). Therefore, a judicious strategy for intraoperative physical and pharmacological liver protection should be implemented. A few decades ago, postoperative mortality following liver surgery or non-hepatic surgery in a patient with liver dysfunction was as high as $50 \%(5,6)$. Substantial improvement in techniques of surgery and perioperative care has made surgery dramatically safer in these patients. Better knowledge of liver pathophysiology has made perioperative liver protection feasible $(7,8)$. Contribution of anesthesiologists to new horizons of safety deserves to be highlighted. High quality organ preservation during liver surgeries by hypothermia, management of intraoperative massive hemorrhage and blood transfusion, appropriate fluid management, postoperative pain control and stress reduction and recently preconditioning by using certain opioids (9-11) and volatile anesthetics (12) are examples of protective strategies implemented by anesthesiologists.

Recent evidences suggest that an exposure to a brief period of ischemia or mild oxidative stress before a severe ischemic insult would help the organ to minimize the sequels of ischemia, a phenomenon known as preconditioning. Several modes of action have been proposed for preconditioning including biological adaptation to injury, direct protection by anti-inflammatory or antiapoptotic mechanisms and finally organ priming by cellular activation of protection (e.g. hemoxygenases-1). A variety of preconditioning methods have been introduced to date such as hyperthermic, ischemic and phar- macological strategies, with variable degrees of efficacy (13). In liver surgery, evidences for less effectiveness of ischemic preconditioning as well as the possibility of increased intraoperative blood loss due to intermittent clamping has made ischemic preconditioning a less favorable choice compared with pharmacological preconditioning (14). Several medications have been proposed for pharmacological liver preconditioning including antioxidants, adenosine agonists, pentoxifylline, proteaseinhibitors, anti-apoptotic substances, prostaglandins, matrix-metalloproteinases-inhibitors and inductors of hemoxygenases 1 (HO-1) (15). Recent laboratory and clinical studies demonstrated a promising role for volatile conditioning $(12,16)$ (Figure 1). A well-designed clinical trial reported that application of sevoflurane for $30 \mathrm{~min}$ utes before the inflow hepatic occlusion would reduce perioperative injury to hepatocytes (12). Interestingly, the protective effect of volatile anesthetics was most pronounced in patients with severe liver steatosis. Several mechanisms have been proposed for hepatoprotective effects of volatile agents including upregulation of HO-1 as an important element in the anti-oxidative system (17, 18) as well as increased production of nitric oxide (NO), demonstrated by up-regulation of inflammatory NO synthase (iNOS) (19).

Historically, it is believed that volatile anesthetics induce liver injury and impair its function. Numerous investigations have focused on hepatotoxic effects of volatile agents for half a century $(5,20-22)$. The story around hepatotoxic effects of volatile agents has come from findings of abnormal liver function tests and morbid outcomes following exposure to older agents such as halothane and enflurane. The incidence of autoimmune hepatitis following exposure to halothane is roughly 1:10000 $(23,24)$. Although controversial, enflurane has been associated with postoperative liver injury $(25,26)$.

Implication for health policy/practice/research/medical education:

Liver surgery and perioperative care of patients with hepatic dysfunction is still moving toward better safety. Anesthesiologists play their role with judicious selection of anesthetic medications.

Copyright (c) 2014, Kowsar Corp.; Published by Kowsar Corp. This is an open-access article distributed under the terms of the Creative Commons Attribution License, which permits unrestricted use, distribution, and reproduction in any medium, provided the original work is properly cited. 


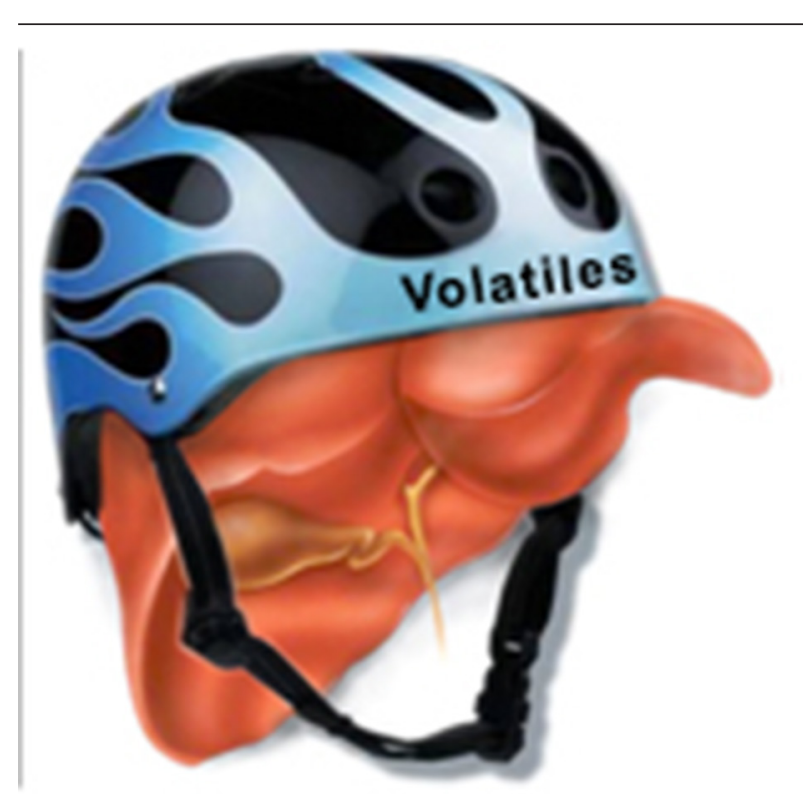

Figure 1. Volatile Anesthetics Should be Tolerated to Protect the Liver in Ischemic Traumas

The pathophysiology of liver injury following exposure to halogenated anesthetics is mainly due to their metabolism to trifluoroacylated hepatic protein adducts which is a hepatotoxic compound. Concerns about decreased cardiac output and total hepatic blood flow when using volatile anesthetics have added to the problem (27). However, newer generations of volatile agents including isoflurane, desflurane and sevoflurane are usually safe because of minimal, if any, biotransformation to trifluoroacylated and even show protective effects.

Isoflurane, an isomer of enflurane, is metabolized to a minimal degree $(0.2 \%)$ and more slowly than halothane or enflurane (28). In spite of minimal biotransformation, isoflurane is accused to be the cause of a wide spectrum of perioperative liver injuries, ranging from transaminitis to fulminant hepatic failure and death (29-31). Contrary to these reports, isoflurane has been shown to protect the liver against ischemia-reperfusion injuries. Laboratory and clinical studies are still underway to clarify the exact mechanism, but isoflurane has been shown to induce an upregulation of HO-1. It seems that induction of $\mathrm{HO}-1$ is related to protein kinase $\mathrm{C}$ and phospholipase A2 independent of nitric oxide or reactive oxygen species (32). In spite of reduced cardiac output, isoflurane also preserves hepatic blood supply, possibly due to direct vasodilatation in the hepatic vascular bed (33).

Sevoflurane does not produce acylated protein adducts and it seems that it is at least as safe as isoflurane (34). Laboratory examinations have shown the promising effect of sevoflurane on the ischemia-reperfusion injury, (35) namely during liver surgery (12).

Biotransformation of desflurane to trifluoroacylated is as low as $0.02 \%(36,37)$. It has been shown to better pre- serve hepatic blood flow than earlier generations of volatile agents such as halothane and enflurane $(38,39)$. A recent clinical trial has suggested that the use of desflurane for maintenance of anesthesia for liver transplantation is associated with better outcome than total intravenous anesthesia (40). Collectively, most of currently available volatile anesthetics have been shown to preserve hepatic blood flow and function (41).

Liver surgery and perioperative care of patients with hepatic dysfunction is still moving toward better safety. Anesthesiologists play their role with optimal intraoperative transfusion and fluid management, pain control, stress reduction as well as judicious selection of anesthetic medications. Certain anesthetic agents such as sevoflurane and isoflurane improve hepatic perfusion and simultaneously protect the liver from ischemia-reperfusion injuries. Further research is required to confirm the hepatoprotective role of volatile agents and optimize their application in different ischemic scenarios.

\section{Acknowledgements}

Our thanks go to Dr Mahsa Motavaf (member of the MELD) for final editing of the manuscript.

\section{Authors' Contributions}

Conception and design, literature search, writing the manuscript: Masood Mohseni, Saeid Safari; scientifically revision of the manuscript: Seyed Moayed Alavian.

\section{References}

1. Bahde R, Spiegel HU. Hepatic ischaemia-reperfusion injury from bench to bedside. Br J Surg. 2010;97(10):1461-75.

2. Fuhrmann V, Jager B, Zubkova A, Drolz A. Hypoxic hepatitis epidemiology, pathophysiology and clinical management. Wien Klin Wochenschr. 2010;122(5-6):129-39.

3. Serracino-Inglott F, Habib NA, Mathie RT. Hepatic ischemia-reperfusion injury. Am J Surg. 2001;181(2):160-6.

4. Clavien PA, Selzner M, Rudiger HA, Graf R, Kadry Z, Rousson V, et al. A prospective randomized study in 100 consecutive patients undergoing major liver resection with versus without ischemic preconditioning. Ann Surg. 2003;238(6):843-50.

5. Heidenberg WJ, Torio IS, Cebula J. Halothane hepatitis. An American disease? Lancet. 1963;1(7292):85-6.

6. Lehmann K, Clavien PA. History of hepatic surgery. Surg Clin North Am. 2010;90(4):655-64.

7. Clavien PA, Petrowsky H, DeOliveira ML, Graf R. Strategies for safer liver surgery and partial liver transplantation. $N$ Engl J Med. 2007;356(15):1545-59.

8. Khajavi M, Emami A, Etezadi F, Safari S, Sharifi A, Shariat Moharari R. Conscious Sedation and Analgesia in Colonoscopy: Ketamine/ Propofol Combination has Superior Patient Satisfaction Versus Fentanyl/Propofol. Anesth Pain Med. 2013;3(1):208-13.

9. Yang LQ, Tao KM, Liu YT, Cheung CW, Irwin MG, Wong GT, et al. Remifentanil preconditioning reduces hepatic ischemia-reperfusion injury in rats via inducible nitric oxide synthase expression. Anesthesiology. 2011;114(5):1036-47.

10. Azmude A, Agha'amou S, Yousefshahi F, Berjis K Mirmohammad'khani M, Sadaat'ahmadi F, et al. Pregnancy outcome using general anesthesia versus spinal anesthesia for in vitro fertilization. Anesth Pain Med. 2013;3(2):239-42.

11. Khan ZH. Pain management in intensive care unit patients: the role of ultra-short acting opioid: remifentanil. Anesth Pain Med. 2013;3(1):188-90. 
12. Beck-Schimmer B, Breitenstein S, Urech S, De Conno E, Wittlinger $\mathrm{M}$, Puhan $\mathrm{M}$, et al. A randomized controlled trial on pharmacological preconditioning in liver surgery using a volatile anesthetic. Ann Surg. 2008;248(6):909-18.

13. Selzner N, Boehnert M, Selzner M. Preconditioning, postconditioning, and remote conditioning in solid organ transplantation: basic mechanisms and translational applications. Transplant Rev (Orlando). 2012;26(2):115-24.

14. Gurusamy KS, Kumar Y, Pamecha V, Sharma D, Davidson BR. Ischaemic pre-conditioning for elective liver resections performed under vascular occlusion. Cochrane Database Syst Rev. 2009;(1):CD007629.

15. Theodoraki K, Tympa A, Karmaniolou I, Tsaroucha A, Arkadopoulos $\mathrm{N}$, Smyrniotis V. Ischemia/reperfusion injury in liver resection: a review of preconditioning methods. Surg Today. 2011;41(5):620-9.

16. Beck-Schimmer B, Breitenstein S, Bonvini JM, Lesurtel M, Ganter $\mathrm{M}$, Weber A, et al. Protection of pharmacological postconditioning in liver surgery: results of a prospective randomized controlled trial. Ann Surg. 2012;256(5):837-44.

17. Maines MD. The heme oxygenase system: update 2005. Antioxid Redox Signal. 2005;7(11-12):1761-6.

18. Ryter SW, Alam J, Choi AM. Heme oxygenase-1/carbon monoxide: from basic science to therapeutic applications. Physiol Rev. 2006;86(2):583-650.

19. Barrier A, Olaya N, Chiappini F, Roser F, Scatton O, Artus C, et al. Ischemic preconditioning modulates the expression of several genes, leading to the overproduction of IL-1Ra, iNOS, and Bcl-2 in a human model of liver ischemia-reperfusion. FASEB J. 2005;19(12):1617-26.

20. Habibollahi P, Mahboobi N, Esmaeili S, Safari S, Dabbagh A, Alavian SM. Halothane-induced hepatitis: A forgotten issue in developing countries: Halothane-induced hepatitis. Hepat Mon. 2011;11(1):3-6.

21. Dabbagh A, Rajaei S. The Role of Anesthetic Drugs in Liver Apoptosis. Hepat Mon. 2013;13(8):e13162

22. Mahboobi N, Esmaili S, Safari S, Habibollahi P, Dabbagh A, Alavian SM. Halothane: How should it be treated in a developing country? EMHJ. 2011.

23. Gut J. Molecular basis of halothane hepatitis. Arch Toxicol Suppl. 1998;20:3-17.

24. Habibollahi P, Mahboobi N, Esmaeili S, Safari S, Dabbagh A, Alavian SM. Halothane-induced hepatitis: A forgotten issue in developing countries. Hepat Mon. 2011;11(1):3.

25. Eger EI, 2nd, Smuckler EA, Ferrell LD, Goldsmith CH, Johnson BH. Is enflurane hepatotoxic? Anesth Analg. 1986;65(1):21-30.

26. Elliott RH, Strunin L. Hepatotoxicity of volatile anaesthetics. $B r J$ Anaesth. 1993;70(3):339-48.
27. Gelman S. General anesthesia and hepatic circulation. Can J Physiol Pharmacol.1987;65(8):1762-79.

28. Holaday DA, Fiserova-Bergerova V, Latto IP, Zumbiel MA. Resistance of isoflurane to biotransformation in man. Anesthesiology. 1975;43(3):325-32.

29. Gunza JT, Pashayan AG. Postoperative elevation of serum transaminases following isoflurane anesthesia. J Clin Anesth. 1992;4(4):336-41.

30. Brunt EM, White H, Marsh JW, Holtmann B, Peters MG. Fulminant hepatic failure after repeated exposure to isoflurane anesthesia: a case report. Hepatology.1991;13(6):1017-21.

31. Turner GB, O'Rourke D, Scott GO, Beringer TR. Fatal hepatotoxicity after re-exposure to isoflurane: a case report and review of the literature. Eur J Gastroenterol Hepatol. 2000;12(8):955-9.

32. Hoetzel A, Leitz D, Schmidt R, Tritschler E, Bauer I, Loop T, et al Mechanism of hepatic heme oxygenase-1 induction by isoflurane. Anesthesiology. 2006;104(1):101-9.

33. Gatecel C, Losser MR, Payen D. The postoperative effects of halothane versus isoflurane on hepatic artery and portal vein blood flow in humans. Anesth Analg. 2003;96(3):740-5.

34. Kanaya N, Nakayama M, Fujita S, Namiki A. Comparison of the effects of sevoflurane, isoflurane and halothane on indocyanine green clearance. BrJAnaesth. 1995;74(2):164-7.

35. Bedirli N, Ofluoglu E, Kerem M, Utebey G, Alper M, Yilmazer $\mathrm{D}$, et al. Hepatic energy metabolism and the differential protective effects of sevoflurane and isoflurane anesthesia in a rat hepatic ischemia-reperfusion injury model. Anesth Analg. 2008;106(3):830-7.

36. Sutton TS, Koblin DD, Gruenke LD, Weiskopf RB, Rampil IJ, Waskell L, et al. Fluoride metabolites after prolonged exposure of volunteers and patients to desflurane. Anesth Analg. 1991;73(2):180-5.

37. Malhotra P, Mychaskiw G, Rai A. Desflurane versus opioid anesthesia for cardiac shunt procedures in infants with cyantoic congential heart disease. Anesth Pain Med. 2013;3(1):191-7.

38. Hartman JC, Pagel PS, Proctor LT, Kampine JP, Schmeling WT, Warltier DC. Influence of desflurane, isoflurane and halothane on regional tissue perfusion in dogs. Can J Anaesth. 1992;39(8):877-87.

39. Weiskopf RB, Eger EI, 2nd, Ionescu P, Yasuda N, Cahalan MK, Freire B, et al. Desflurane does not produce hepatic or renal injury in human volunteers. Anesth Analg. 1992;74(4):570-4.

40. Ko JS, Gwak MS, Choi SJ, Kim GS, Kim JA, Yang M, et al. The effects of desflurane and propofol-remifentanil on postoperative hepatic and renal functions after right hepatectomy in liver donors. Liver Transpl. 2008;14(8):1150-8.

41. Kotake Y. [Anesthetic protection against hepatic injury]. Masui. 2006;55(5):570-8. 